\title{
Seismicity of Mosul Dam Reservoir for the Monitoring Year 1990
}

\author{
Nabeel H. Al-Saigh \\ Dams and Water Resources Research Centre \\ Mosul University
}

(Received 8/5/2011, Accepted 30/6/2011)

\begin{abstract}
Seismic activity has been studied at Mosul dam reservoir for the period January to $20^{\text {th }}$ July 1990.33 micro-earthquakes of magnitude up to 3 ML were located. Nearly all earthquake epicenters were located within a radius of less than $25 \mathrm{~km}$ from the dam site. All the hypocenters, except one, were located at depth less than $2 \mathrm{~km}$ from the lake's surface, which means there is no change occurred in the seismicity behavior from the previous monitoring period March 1986 to end of December 1987.

Key words: seismicity, earthquake

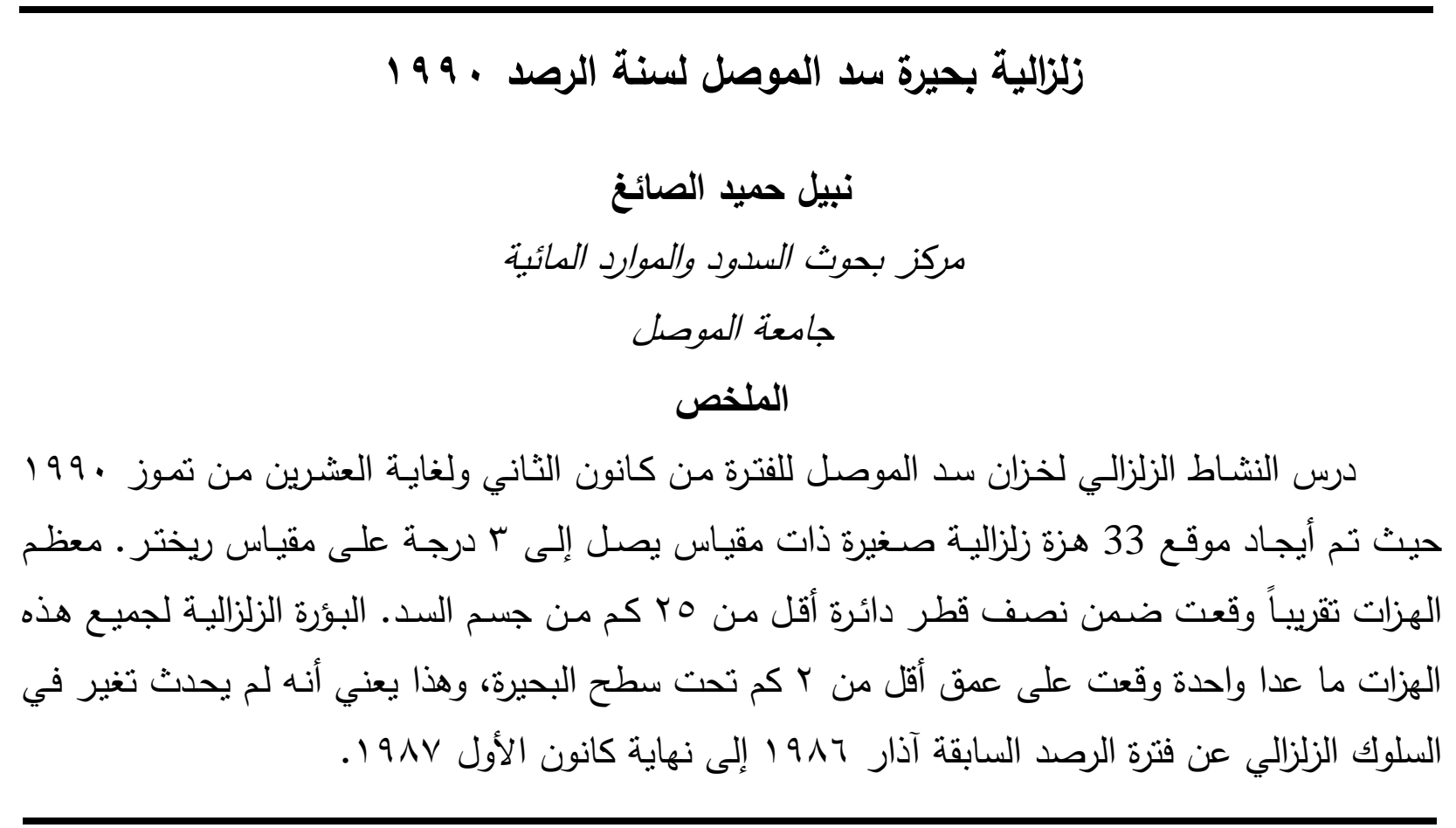

\section{INTRODUTION}

The seismicity of Mosul reservoir was studied by (Al-Saigh, 2008), for the monitoring period March 1986 to end of December 1987, (while Al-Saigh, 2010) discussed the mechanism of the induced earthquakes at Mosul reservoir using the first motion of P-waves.

New seismic data were recently obtained for the monitoring period January to $20^{\text {th }}$ July 1990 where this study has been conducted. The earthquakes were located 
by applying the HYPO71 program written by Lee and Lahr (1972) and using a crustal velocity model for the area suggested by Al-Saigh and Toffeq (1993). These data will provide a great opportunity to make correlation with the earthquakes located in the previous monitoring period and to show the behavior of induced earthquakes in the area after stopping the seismic network in the area for more than two years due to technical problems (1988 and 1989). The seismic network in the area, unfortunately, had been destroyed completely during the 1990 Gulf war, and the present data are the last monitoring data.

\section{GEOLOGICAL AND TECTONIC SETTING OF THE AREA}

The main exposure rocks in the study area are the Fat ha Formation (M. Miocene), while the Injana (U. Miocene), Miqdadia (Pliocene) and Pila-Spi (M. U. Eocene) Formations cover rest of the area (Fig. 1).

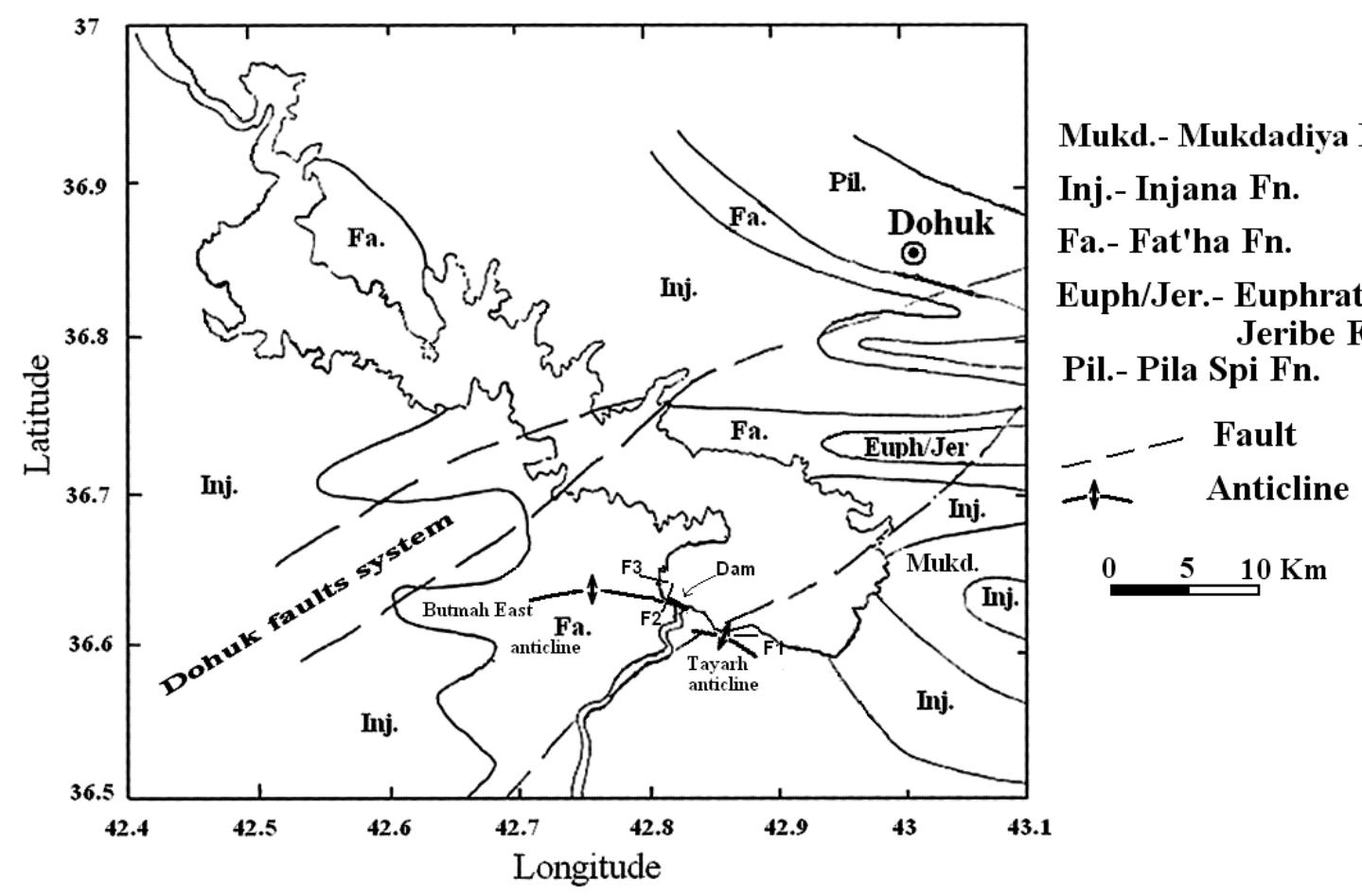

Fig.1: Geological Map of Mosul's Dam Lake (Modified from the Geological Map, 1986 and Tectonic Map of Iraq, 1984).

The dam site is bounded by two anticlines trending E-W; namely Tayarh and Butmah East anticlines. Tayarh anticline is located on the eastern side of the Tigris River. It is a small anticline of about $4 \mathrm{~km}$ long and $0.5 \mathrm{~km}$ wide. Butmah East anticline, on the other hand, is located on the western side of the river. It is about $12 \mathrm{~km}$ long and $3.5 \mathrm{~km}$ wide (Tawfiq and Domas, 1977).

Tectonically, the whole reservoir lies within the Sinjar block. The block lies only partly in Iraq, continuing westwards into Syria and Turky (Kassab and Abbas, 1987). Its superficial and subsurface structures are mostly E-W oriented and relatively long. The south-south eastern boundary of the block is 
expressed on the surface by a complex fault zone which is called the SinjarDohouk-Kuchuk Faults System. This fault is bounded the southern border of Mosul reservoir.

A gravity survey carried out by (Al-Ansari, et al. 1984) suggested the presence of three faults (F1-F3) in the area; one cutting the northern limb of Tayarah anticline with an E-W trend, which is most probably, represents a part of Dohuk fault system. The second fault cuts the northeastern corner of the eastern plunge of Butmah East anticline, and extending in an E-W direction towards the dam. The third fault is trending NNE-SSW along the western bank of the river.

\section{SPATIAL DISTRIBUTION OF SEISMIC EVENTS}

More than 65 earthquakes were identified, of which 34 were located. Only events recorded on three or more seismic stations were considered. Most of the events, however, were recorded on three stations. The time difference between (P and $\mathrm{S}$ ) arrival times were considered in the earthquakes location.

(Fig. 2) is a plan view showing the spatial distribution of earthquake epicenters in the area. Nearly all the epicenters were located within a radius of less than $25 \mathrm{~km}$ from the dam site. The majority of the epicenters were located in the lake region, in the area between the Dohuk faults system. The width of this zone is about $17 \mathrm{~km}$. No seismicity was observed along the three faults (F1-F3) that had been identified by the gravity survey (Al-Ansari, et al. 1984).

(Fig. 3) is a vertical section showing the distribution of earthquake hypocenters with depth. Most of the hypocenters were located between the surface and $2 \mathrm{~km}$ deep. Very few were located between $2 \mathrm{~km}$ and $4.5 \mathrm{~km}$ deep.

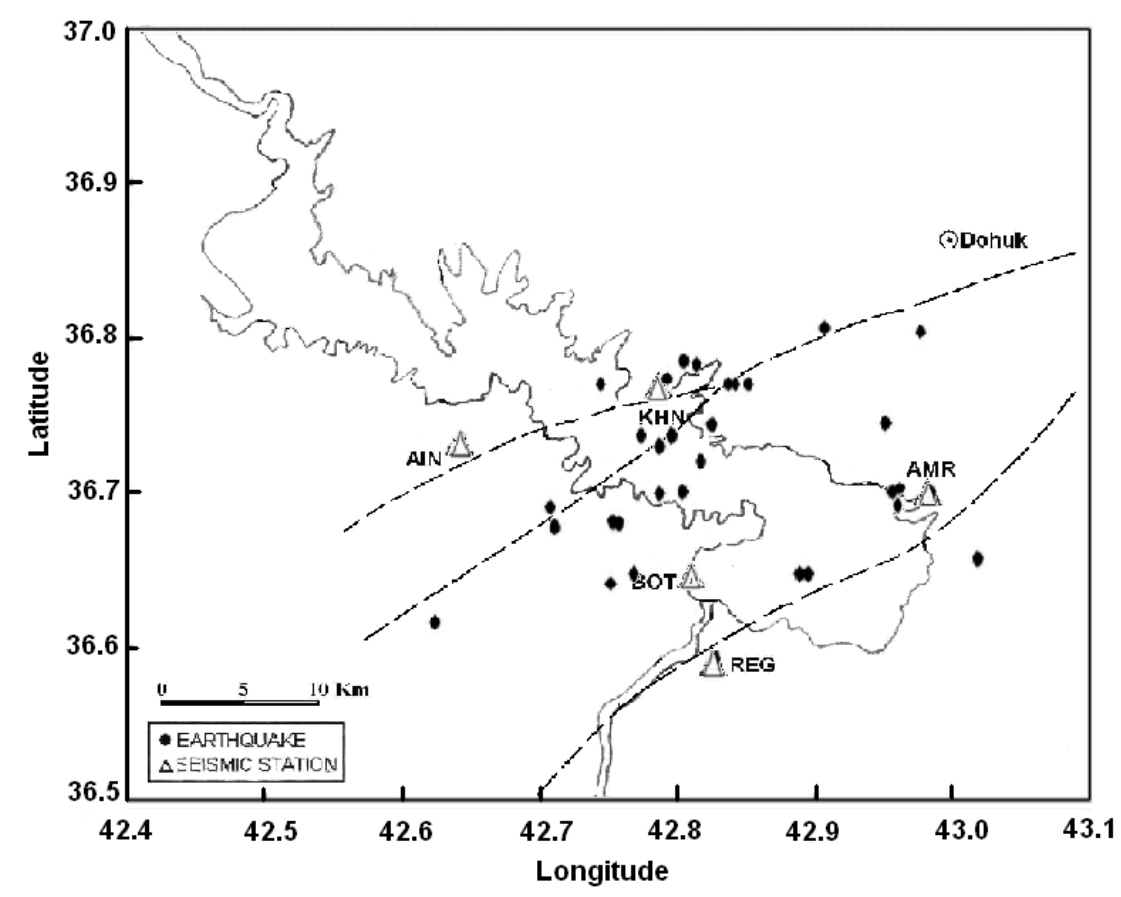

Fig. 2: Seismicity Map of Mosul's Reservoir for the Monitoring Period January to $20^{\text {th }}$ July 1990. 

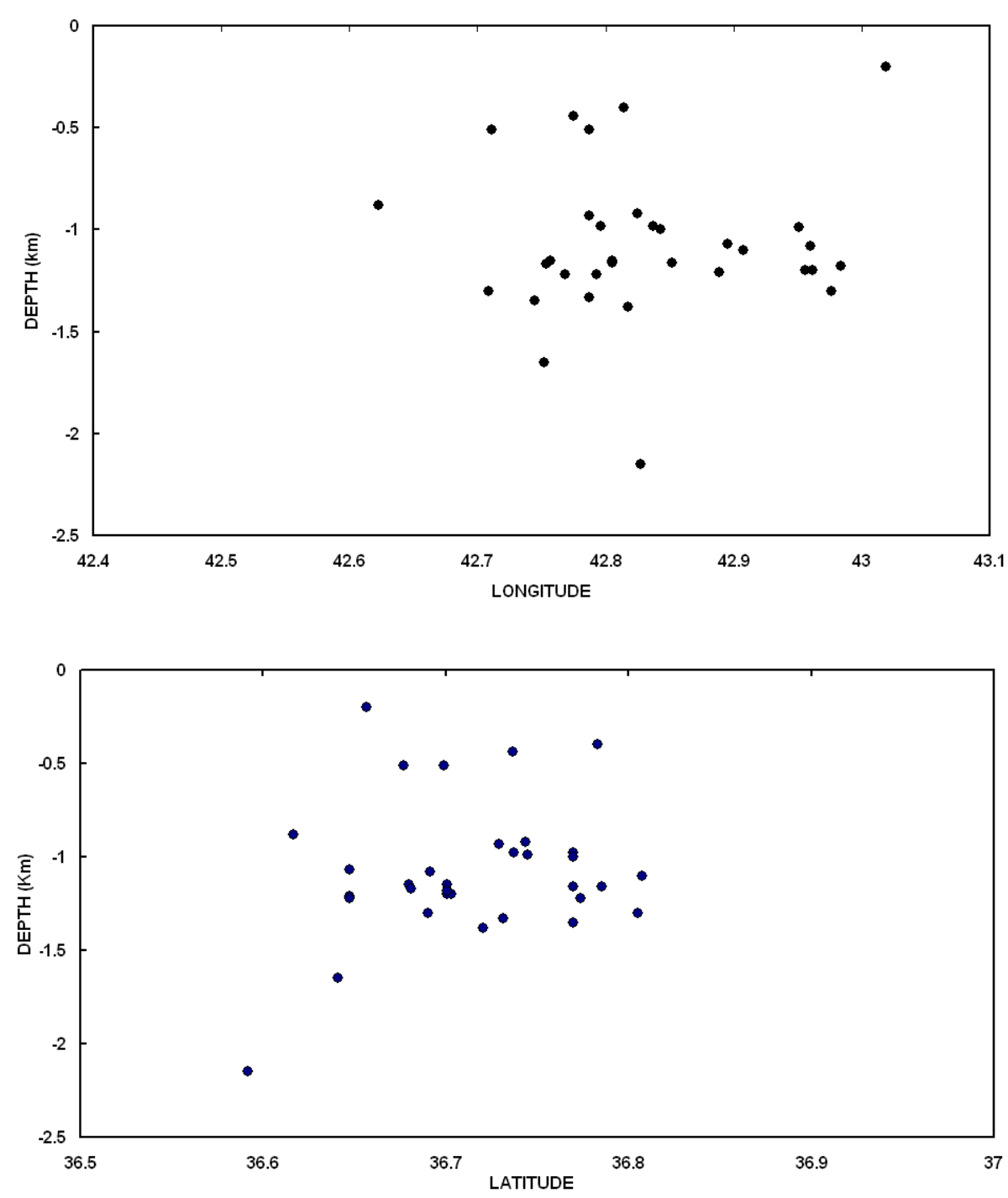

Fig. 3: Vertical Distributions of Earthquakes' Hypocenters.

\section{RESERVOIR LEVEL AND EARTHQUAKE FREQENCY}

Because of instrumentation problems not all earthquakes could be located; hence the earthquake catalog shows fewer events and is not representative during the time period, as an example the network was idle during all June. Therefore there is no obvious relation between the number of earthquake occurrence and the level of water in the lake (Fig. 4).

(Fig. 5) shows the cumulative number of located earthquakes during the monitoring period. Linear regression fitting suggested that the average seismicity level was more than 1.5 events per day. 


\section{MAGNITUDE DETERMINATION}

Magnitude is a quantitative empirical scale used to measure the size of earthquake instrumentally. Earthquake sizes were determined as ranging between 0.0 and 3.0 ML using the magnitude-duration relationship.

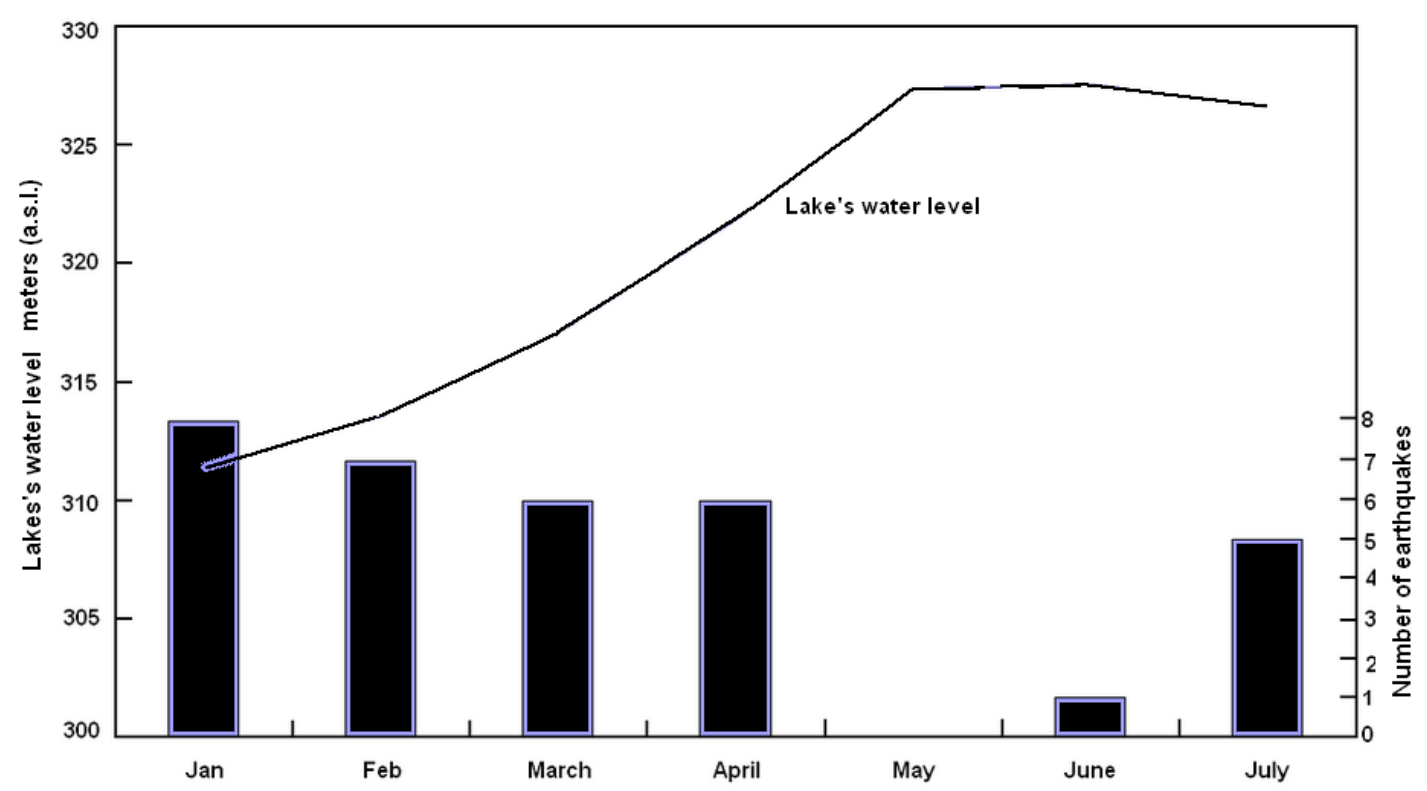

Fig.4: The Relationship between the Lake's Water Level and the Number of the Located Earthquakes, During the Monitoring Period.

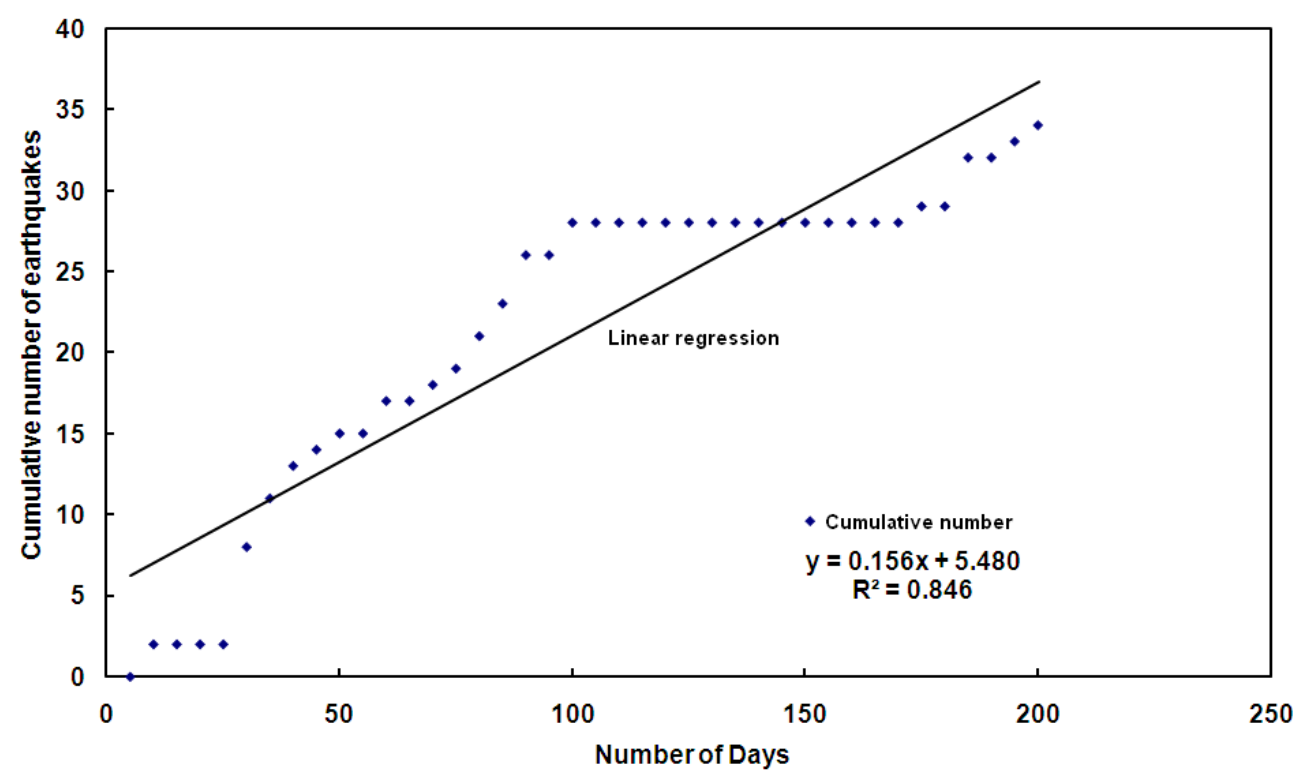

Fig. 5: Cumulative Numbers of Earthquakes Against Days of the Year.

$\mathrm{MD}=2.0 \log \mathrm{D}-0.87$

Where $\mathrm{MD}=$ duration magnitude

$\mathrm{D}=$ signal duration from $\mathrm{p}$-wave onset to the end of discernable signal. 
This relationship was determined for California (Lee et al. 1972). While the magnitudes determined using this formula may be slightly biased in terms of any absolute comparison with magnitude scales used elsewhere, it provides an acceptable measure of the relative sizes of the earthquakes at Mosul reservoir.

\section{CONCLUSIONS}

It is obvious that induced seismicity for the monitoring period 1990 resemble the induced seismicity for the monitoring period 1986-1987 in both space and time. This clearly suggests that factors affecting the sesimicity in the area are the same factors that generate the seismicity in the previous monitoring period and did not alter through the time.

\section{ACKNOWLEDGEMENTS}

I am greatly indebted to the Directory of Mosul Dam for providing the seismic records.

\section{REFERENCES}

Al-Ansari, N. A., Barazanji, M. A.; Al-Jabbari, M. H. and Gayara, A. D., 1984. Geological investigation of Mosul dam site. Directorate of Mosul Saddam Project. Internal Report.

Al-Saigh, N. H., 2008. Seismicity of Mosul dam reservoir. Iraqi Journal of Earth Sciences. Vol. 8, No. 2, pp. 11 - 16.

Al-Saigh, N. H., 2010. The mechanism of induced seismicity at Mosul reservoir based on the first motion analysis. Journal of the Geological Society of India, Vol. 76, October 2010, pp. 399 - 402.

Al-Saigh, N. H. and Toffeq, I. N., 1993. Geological and geophysical study of the southern part of Saddam reservoir. Iraqi Geological Journal, Vol. 27, No. 2, pp. 150 - 161.

Kassab, I. M. and Abbas, M. J. (Edit) 1987. The Regional Geology of Iraq, Tectonism, Magnatism and Metamorphism. Directorate of Geological Survey and Mineral Investigation. Baghdad.

Lee, W. H. K. and Lahr, J. C., 1972. HYPO71, a computer program for determining hypocenter, magnitude and first motion pattern of local earthquakes. U. S. Geological Survey, Open File Report, 100 p.

Lee, W. H. K., Bennet, R. E. and Meagher, K. L., 1972. A method of estimating magnitude of local earthquakes from signal duration. U.S. Geological Survey, Open File Report, 28 p.

Tawfiq, J. M. and Domas, J., 1977. The regional geological mapping of DohukAinzalah area. Unpublished Report. State Organization of Mineral Library, Baghdad, Report No. 837. 